Portland State University

PDXScholar

$5-25-2019$

\title{
The Liberal and the Limits of Discourse in Waiting for the Barbarians
}

Matt W. Cardoza

Portland State University

Follow this and additional works at: https://pdxscholar.library.pdx.edu/honorstheses Let us know how access to this document benefits you.

\section{Recommended Citation}

Cardoza, Matt W., "The Liberal and the Limits of Discourse in Waiting for the Barbarians" (2019).

University Honors Theses. Paper 727.

https://doi.org/10.15760/honors.745

This Thesis is brought to you for free and open access. It has been accepted for inclusion in University Honors Theses by an authorized administrator of PDXScholar. Please contact us if we can make this document more accessible: pdxscholar@pdx.edu. 
The Liberal and the Limits of Discourse in Waiting for the Barbarians

\author{
by \\ Matt Cardoza
}

An undergraduate honors thesis submitted in partial fulfillment of the

requirements for the degree of
Bachelor of Arts
in
University Honors
and
English

Thesis Adviser

Sarah Lincoln, Ph.D.

Portland State University 


\begin{abstract}
Although it has remained a prominent work of literature since its 1980 publication, there has been a considerable resurgence of academic interest in J. M. Coetzee's Waiting for the Barbarians in the wake of 9/11, particularly as the novel's attention to torture, imperialist violence, and the ideological construction of civilization/barbarism oppositions became increasingly relevant to the escalating "war on terror." A great deal of that scholarship has taken the form of poststructuralist analyses of the discursive production of barbarian "others" as legitimate targets of violence and domination by the empire within the novel. This paper is largely a critique of a prevailing liberal humanist current that runs throughout much of the contemporary critical works, an ideological framework that I argue Coetzee's novel is itself a critique of. Using a methodology influenced by cultural materialism and new historicism, I perform side-by-side readings of the Barbarians and essays by Maria Boletsi, Liani Lochner, and Robert Spencer to explore the liberal convictions that the critics' perspectives share with the novel's narrator, the Magistrate. Specifically, I find that the core thread tying these perspectives together is what I refer to as the logic of understanding, the liberal desire to know the other-an assumption that the violence committed against the other is legitimized by virtue of our lack of understanding them and a faith that we can combat imperialist violence by expanding our capacity to know the other. I argue that the novel is unequivocal in demonstrating that the liberal logic of understanding is not a challenge to the structures of imperialism but actually a reflection of its core ideological foundations.
\end{abstract}


The Liberal and the Limits of Discourse in Waiting for the Barbarians

A veritable river of scholarly ink has been spilled over J. M. Coetzee's Waiting for the Barbarians, and among the litany of critical works, a formidable segment of them have concerned themselves with applying poststructuralist lenses to the novel's engagement with the subject/other, civilization/barbarism opposition as ideological foundations in regimes of imperialist violence. It is not hard to see why this has been the case; Coetzee's novel and its concern for the questions of complicity and resistance in relation to the violence of empire have continued to appear both timely and timeless since its publication. Moreover, his complex and unflinching fixation with the seemingly intractable dilemma of the subject's inextricability from linguistic networks of violence, domination, and othering is impossible to overlook as a core feature in nearly all of his work. Throughout much of the scholarship in question, however, a distinct pattern can be seen to take shape. Namely, a considerable number of recent critics, regardless of differences in approach or direction, share what appear to be relatedly liberal conclusions regarding the novel's ultimate takeaways - that the political and ethical success of Barbarians lies in its ability to situate the reader's perspective within that of the Magistrate's development; that the novel functions to give us the tools by which to subvert the dehumanization of the other as a discursive function of dominant ideology; that it works to expose and make visible the violence perpetrated against the other and in doing so establishes the common ground for our mutual humanity in the vulnerability of the body to pain and suffering; and perhaps underlying all of these notions, that the essential telos of Barbarians is organized around cultivating the means by which we can come to break through the dehumanization of othering by some form of heightened empathy and understanding. 
What alarms me, or at the very least appears strikingly out of place in all this, is the decidedly liberal and humanistic tone of so many recent academics' readings of a novel that is so adamantly critical of liberalism and humanism as forms of moralistic quietisms entrenched in master discourses. ${ }^{1}$ Ultimately it appears to me that this dissonance arises from a number of core assumptions these critics actually share with the Magistrate, which remain unquestioned throughout their readings - namely, the belief that the oppression of the other is perpetuated through a failure on the part of the subjects of imperialism to fully understand them beyond their dehumanization, and that systems of violence and domination are to be overcome by reasserting the other's humanity through an expanded capacity to understand them. While it seems quite clear that the impossibility of this thinking, and its overall complicity in the other's oppression, is precisely the hard-earned insight the Magistrate has gained at the novel's conclusion, I would also argue that the other is only created as an object that can and must be understood through the structures that necessitate their violent domination. That is, imperialist exploitation and oppression dehumanizes its targets - and thereby produces their illegible otherness - as a byproduct of that necessitated violence, and it is precisely this byproduct that incites the logic of Colonel Joll's interrogations and torture as well as the Magistrate's urge to read, to translate, to understand the barbarians. My frames of reference here are primarily to be: Maria Boletsi's "Barbarian Encounters: Rethinking Barbarism in C. P. Cavafy's and J. M. Coetzee's Waiting for the Barbarians," Liani Lochner's "Literary Form and Contesting the Subject in J. M. Coetzee's

\footnotetext{
${ }^{1}$ That this trend is primarily seen in recent scholarship may not be insignificant. For a juxtaposition with South Africa's political and intellectual climate at the time of Barbarian's publication, see Peter Blair's "The Liberal Tradition in Fiction." In particular, he notes a widespread disregard on the left for liberalism as "a quietist ideology complicit with colonialism rather than a ... credible oppositional strategy," a view that would remain commonplace until a revisionist lionization of liberal values took place after the fall of apartheid-perhaps not unrelated, as well, from the beginnings at that time of a transition from revolutionary politics towards today's neoliberal status quo. $(477 ; 478)$.
} 
Waiting for the Barbarians and Avarind Adiga's The White Tiger," and Robert Spencer's “J. M. COETZEE AND COLONIAL VIOLENCE." Each of these works present fairly recent and insightful poststructuralist readings of Coetzee's novel (Boletsi's 2007 publication makes hers the oldest of the three), and each is situated with an eye to the war on terror. While all of the works take, to some extent, different aspects of the novel into consideration, they nonetheless bear striking similarities in the liberal nature of their ultimate conclusions.

In his chapter "The Liberal Tradition in Fiction," Peter Blair lays out a useful set of tentative definitions of liberalism, which will help concretize what I mean by classifying the convictions of critics as liberal. He offers Alan Paton's list of liberalism's characteristics: “a generosity of spirit, a tolerance of others, an attempt to comprehend otherness, a commitment to the rule of law, a high ideal of the worth and dignity of man, a repugnance for authoritarianism and a love of freedom" (qtd. in Blair 475). Of additional interest are some of David Welsh's "core values of liberalism," which Blair also relates, specifically those of "a commitment to fundamental human rights, ... a belief in equality, ... tolerance of conflicting viewpoints," as well as "an optimistic belief in the possibilities of individual and social 'improvement," and finally, the importance of "compassion" (qtd. in Blair 475). While, as will be seen, many of these are key features of the critical works I am concerned with, this taxonomy also draws considerable parallels to the Magistrate as we encounter him at the novel's outset.

As the story unfolds, the Magistrate emerges as the paradigmatic liberal within a social structure of violence and oppression, the embodiment of the liberal's conflicted existence within an empire. These characteristics play out in the disposition with which he occupies his office as a civil servant. Like most liberals, the Magistrate eschews fervent patriotism, and his position of authority is something he performs with a kind of casual or reserved moderation, rather than 
passionate enthusiasm. Often, he describes his service to the Empire with a sense of duty, rather than as a source of pride. He dismisses the paranoia about the barbarian threat, the current "episode of hysteria," that has animated the fears of the townspeople and Empire as "dreams ... the consequence of too much ease" (9). Although he is an official of the Empire, his tolerant sensibilities dispose him to a level of disgust for the Empire and its subjects' ignorant animosity towards the barbarians. And he certainly embodies the charity, the sense of open-mindedness, and the distaste for open displays of prejudice characteristic of liberals. We find further reflections of his character in his fondness for decorating his apartment with the outsiders' artifacts, his willingness to learn the frontier patois so that he can communicate with the visiting nomads, as well as his more broadly informed understanding of the differences between the fisherfolk tribes and the nomads.

His liberal attitude is well encapsulated by his reflections on the annual winter visits of the nomads - a tradition, to his dismay, disrupted by Colonel Joll's aggressions. The Magistrate notes his progressive promotion of "commerce" between the fort and the nomads, as well as his paternalistic reasoning for preventing the nomads from trading in currency or being given access to alcohol — his worry that without precautionary measures they would be swindled by the shopkeepers and taverns and turned into "a parasite settlement" of "beggars and vagrants enslaved to strong drink" (43). Although his underlying concern about "confirming thereby the settlers' litany of prejudice" is certainly telling (and we will have occasion to return to this), his conclusion, "Where civilization entailed the corruption of barbarian virtues and the creation of a dependent people, I decided, I was opposed to civilization," resonates quite well with common liberal persuasions (43). His paternalistic efforts to protect the nomads from themselves, his concern that their exploitation might confirm stereotypes he finds distasteful, and most of all his 
high-minded valorization of "barbarian virtues" over the corrupting force of "civilization," all smack of the patronizing liberal sentiments that underlie the noble savage trope. His tolerant disposition towards the unfairly treated nomads betrays, in his very pronouncement of tolerance, its own entrenchment within the ideology of the Empire.

In considering the critical work on Coetzee's novel, Maria Boletsi's article is an exemplary case. She situates her argument in relation to the legacy of $9 / 11$, with an appeal to the resurging relevance of Coetzee and Cavafy's texts and their central engagements with the civilization/barbarism dichotomy. She argues that both texts "play on this opposition and disrupt the fixity of the relation between its two constituents," doing so not only in a way distinct from other historical precedents but crucially from a reflective position within the inescapable "authoritative discourse of history" that (re)produces the dichotomy (71). Boletsi identifies the texts' uses of uncertainty, present tense, historical ambiguity, and first-person narrative as the literary structures that enable the works to operate "as instances of historical and cultural memory through performativity," an operation that exposes the function of historical discourse to naturalize and objectify categories and oppositions into fixed entities $(83 ; 82)$. In regards to Coetzee, through close reading of the way "barbarian" as a term develops throughout the novel, Boletsi ultimately illustrates how Empire's overuse of the word without real referent delegitimizes the discursive regime, simultaneously feeding into the Magistrate's reconfiguration of the binary in light of the Empire's own barbarism (88). The novel does not give way to a simple reversal, but rather, in continuing both uses through its entirety, Barbarians "destabilizes the opposition by rendering it unnatural and arbitrary" (89). Boletsi's compelling article stands out as a nuanced and sophisticated reading of the text, skillfully elucidating how the novel presents "unresolved questions, linguistic bewilderment, obsessive iterations, infelicitous 
performatives, and the desire for an alternative way of thinking and speaking" to the reader as a performative event with the capacity to destabilize the discursive legitimacy of the imperial project (94). Her closing thoughts, however, that through all this the novel gestures towards the hope "of a society that would not need to wait in vain for the barbarians, but would be more open to an encounter with others," terminate in a surprisingly liberal sentiment that rings somewhat hollow (94).

While I do not wish to be unfair to Boletsi-and it ought to be acknowledged that I am doing little justice to the substance of her reading here- - I will at the very least argue that her closing appeal seems ill fitted to Coetzee's novel: the ending, regardless of how one is to read it, certainly seems anything but hopeful about whatever being "more open to an encounter with the other" might entail. Though I am not (or at least not yet) interested in making more out of it, there is much to be said about the kind of futurity in the Magistrate's anticipation of the coming of the barbarians, his fantasy that their descent on the town might be led by the barbarian girl he knew, and his rumination, "Then everything will be on new footing" (Coetzee 76). However, like the "wind of utter desolation" that his memory of her bears down on him in the moments preceding that reflection, our final glimpses of the town "composing their souls as they [wait] for the barbarians" and the depths of winter approach, as well as the Magistrate's apocalyptic preoccupation with themes of ruin and the question of what is "to be left for posterity buried under the walls of our town," do little to incline us towards an interpretation of that futurity as a reconciliatory encounter with the other $(176 ; 178)$. This is not to say that these passages can or should be taken on their own or at face value (as is the case with much of this text), nor am I suggesting that the futurity underlying them is the same terror and paranoia about the barbarians 
that the Empire perpetuates. ${ }^{2}$ Rather I wish to make little of these passages or their significance as yet, beyond an indication of the dissonance between the novel's ending and Boletsi's optimistic visions of pluralism.

It should be well noted that Boletsi is not alone in drawing discordant conclusions from sophisticated poststructuralist analyses of the novel, although few attain to her level of acuity, depth, or insightfulness. Robert Spencer, for instance, argues that through the narrative of the novel, Coetzee "starts a new morality from scratch, based not on pious abstractions but on suffering's incontrovertible eloquence," which might appear innocuous enough on its own (186). This line of reasoning, however, ultimately leads Spencer to the decidedly liberal conclusionand he is here, like Boletsi and Lochner, thinking of Barbarians in relation to the war on terror and the atrocities of Abu Ghraib - that "atonement" for the injustices of imperialism "entails respect for the rule of law, for the numerous indefeasible covenants by which torture is outlawed," meaning international human rights statutes, "and for the idea and practice of humanism"3 (186). Liani Lochner's reading of the novel seems to share distinct echoes with the others, evident in her depiction of the Magistrate's (and thereby the novel's) project as “forging a space for the realization of a common humanity with the barbarians," something she recalls Spencer in identifying the universality of our bodily vulnerability to violence as "the site for the formulation of an affective recognition of the other" (242). It might be noted that there is a difference in my consideration of these other two and Boletsi; the issues I take with these other writers are clearly tied to their readings and arguments about the text, whereas my confusion is

\footnotetext{
${ }^{2}$ And it must be insisted that, whatever is being expressed in the novel's ending, it is unequivocally a futurity. Even apocalypse is a kind of futurity, one that we may well find is radically different from the Empire's projections.

${ }^{3}$ Out of a sense of responsibility, a more detailed reflection on the concerning aspects of Spencer's argument, which could not be made to fit into the text of this essay or a footnote, has been moved, at the risk of violating consistency of format, to a digressionary note after the essay's conclusion.
} 
aroused by Boletsi's incongruent conclusions about the novel precisely because her reading seems so compelling and astute.

That her sentimental appeal follows what is an otherwise thoughtful and nuanced examination of the text, demands some form of explanation, as it is clearly not the product of a failure to comprehend the text. In fact, it must be reiterated that the need to further interrogate her essay is sparked specifically because so much of it seems an essentially accurate and insightful reading of the novel. What is more, the extent of her accuracy to the text makes finding exactly where one might take issue a matter of digging. This essay's point of departure with her reasoning begins to take shape, however, during her discussion of the Magistrate's relation to the barbarian girl, in whom, Boletsi notes, "the Magistrate sees the possibility of making contact with the other" (80). To be precise, I am concerned with how Boletsi conceptualizes the mechanism of obstruction in the Magistrate's pursuit of contact with the barbarian girl. "His approach," Boletsi notes "is incurably marked by the logic of understanding as penetrating and deciphering, so typical of the colonial attitude toward the colonized" (79). The issue I take with her point is not easily located; the implication that ultimately causes me to linger on it almost entirely hinges on the function of a single word, as.

Boletsi's argument here, that the problem is the Magistrate's mode of understanding, "understanding as penetrating and deciphering," which she condemns as a reflection of "the colonial attitude toward the colonized," is underpinned by the assumption that there exists another mode of understanding within colonialism — that the other is knowable, just not through this particular method. In her following reflections, Boletsi locates a certain victory in the Magistrate's refusal to "impose his own voice on [the barbarian girl]" even in the face of his frustrated attempts to understand her, a gesture that Boletsi finds promising in that it "shows his 
willingness to live with difference" (80). Her suggestion, "The 'waiting' of the novel's title" could be read in the sense of "waiting for the other to speak" without imposing our words on them, along with her anticipation that "the promise" of the other's voice, as a voice of difference, will "be the first step toward a reciprocal approach on equal terms," bring us into full view of the logics that underlie and inhibit Boletsi's essay (80). We have three assumptions being expressed here, not uncommon to liberal thinking in general: one, that what dooms the Magistrate's attempts to understand the barbarian girl is the type of understanding he deploys; two, that the fault in his type of understanding is the degree to which it reflects the Empire's colonialism; and three, that the knowledge to be gained from the correct type of understanding could be the grounds for establishing some form of equality between the Magistrate and the barbarian girl. If we reconstruct this into a formula, what we get is that the other is knowable, that it is the result of colonialism that we fail to know them, and that knowing them is the means by which we undo their oppression and move towards a greater level of equality. Coupled with the common presumption that the other is oppressed because they are dehumanized, this latter point takes on the dimensions familiar in liberal sentimentalism: that the other can be rehumanized in the eyes of the oppressor society by proving their humanity through a greater degree of understanding.

While we could continue with Boletsi's article further, for now it is sufficient to recognize the presence of a tacit commitment to the ability to and potential for (or even necessity of) understanding the other as the liberal principle that undergirds her thinking. Once more, Boletsi is not alone, although she is distinct in that what is a subtle undercurrent in her essay threatens to overthrow the thoughts of others. In fact, a similar logic seems to be the very basis of Lochner's essay. Lochner argues that systems of violence and oppression "operate to produce and maintain certain exclusionary conceptions of the subject; they establish a frame for who can 
be perceived as a legitimate subject in society" and through these 'exclusionary conceptions,' regimes justify and perpetuate "differential exposure to violence" onto those they establish as others (237). For Lochner, by "staging the performativity of social identity," literature challenges "the recognizability of others within a particular social configuration" (237). Here we find an even more explicit embrace of the logic of understanding hidden in Boletsi, as Lochner articulates her faith in literature's capacity to, by offering us access to alterity, "initiate fresh possibilities of feeling, perceiving, responding, behaving towards the other and thus challenge existing schemes of intelligibility" (237). What is a barely expressed assumption in Boletsi's thinking, the knowability of the other, is the basis of Lochner's liberatory framework: that regimes of dominance justify their violence by hiding the other's humanity from us, that exposure to the other allows us to recognize them — that is, they become intelligible — and through the knowledge of the other acquired by our access to their alterity, we recognize their mutual humanity and cease to tolerate the violence committed on them.

When we strip away the layers of academic language and theoretical lenses, the basic reasoning that animates this analytic direction is something quite commonplace: namely, that oppressed groups are and continue to be oppressed as a result of the bad (inaccurate, negative, distorted, false, prejudiced) ideas that the people of dominant groups have about their difference. By virtue of that condition, the solution to oppression begins with or is a matter of changing and correcting the bad (ignorant, faulty, racist, backward, etc.) ideas that dominant groups hold and perpetuate. There is, of course, a question about empathy lurking in this as well, but I will have to address that at a later date. For the time being, it remains significant that this is the very same logic that defines the Magistrate's liberal outrage over the Empire's animosity towards the barbarians. In his argument with a young officer about the Empire's military offensive, the 
Magistrate reduces that animosity and the injustices it occasions to a product of contempt "founded on nothing more substantial than differences in table manners, variations in the structure of the eyelid" (58). In his self-critical inner dialogue that follows, "Do I really look forward to the triumph of the barbarian way: intellectual torpor, slovenliness, tolerance of disease and death?" the Magistrate exposes the pretensions of the noble savage trope reflected in his pious rejection of imperial superiority (59). Moreover, he challenges the veracity of his own liberal commitments, wondering if his "indignation at the course that the Empire takes" is "anything more than the peevishness of an old man who does not want the ease of his last years on the frontier to be disturbed" (59).

Of course, behind the liberal conception of oppression, as a product of ignorance, is the implicit belief that the other is other by virtue of our lack of knowledge about them. The liberal humanist logic of understanding that governs all this, coupled with the obsession with knowing the other in relation to the violence done to them, can readily be seen to dominate the Magistrate's relationship with the barbarian girl. Boletsi rightly notes, "In the barbarian girl the Magistrate sees the possibility of making contact with the other," however she shows little interest in interrogating what motivates this desire for contact (79). Regardless of why it is that Boletsi accepts it without question, I do not believe that the desire for contact is so cut and dry as to warrant being taken at face value. After all, the Magistrate's immediate reflection on first meeting with the barbarian girl, "The distance between myself and her torturers, I realize, is negligible," makes it clear that his personal sense of guilt in the Empire's atrocities, his complicity in her suffering, is a driving force in his interest with her (Coetzee 32). That is, his charity, his concern, his fascination with her and the possibility of contact is bound up with his desire for repentance and redemption from his feelings of guilt. It seems reasonable, then, that 
his initial efforts to know her manifest as a compulsive urge to learn about the torture that she was subjected to, the source of his guilt and obligation to her.

His guilt can be seen driving the dialogue between himself and the girl that immediately follows his above recognition, in which the Magistrate first gives voice to what will soon become an all-consuming obsession, "Show me your feet ... Show me what they have done to your feet" (32). Over and over again, their interactions revolve around and are often terminated by his insistent reformulations of the same questions, "What did they do to you? ... Why won't you tell me?" (36). This, at least in part, seems to animate his erotic fixation with washing her body, massaging her, running his fingers over the "phantom criss-cross of ridges under the skin"; after a fashion, these are attempts to read the damage on her body and discover what was done to her (36). The novel calls attention to this corollary of the imperative to understand the other: the need to read them, to decipher the significance that their immediate presence does not admit to us. When she refuses to share with him that knowledge, the Magistrate goes so far as to question the guards who were involved with Colonel Joll's interrogations. While Boletsi is not wrong in stating that the Magistrate "does not force [the barbarian girl] into" answering him, just as he does not overtly "impose his own voice on her," it is hard to see anything one might call respectful of her silence in his sideways attempts to violate the boundaries she has set on his knowledge of her (Boletsi 80). In his dawning certainty that he will be bound by this obsession "until the marks on this girl's body are deciphered and understood," the Magistrate gives voice to the inextricability of his attraction to the girl and his compulsive desire to uncover the truth of her torture, both manifested in this practice of reading her body (35).

Given this essay's suspicions regarding the deeper convictions about understanding that animate his urge to uncover the truths of the barbarian girl's torture, it is unsurprising that her 
eventual confession of those details, her laying bare the object of his inquisition, does nothing to set to rest his investigative compulsions towards the girl. Instead, the Magistrate's discovery of the concrete facts that make the girl's scars legible—-the successful translation of those markings - only serves to heighten his feelings of incomprehension and exacerbate his obsession with interpreting her. However, it is no longer the girl's scars that present him with a mystery demanding to be deciphered, but the girl herself. He struggles to construct a mental image of her beyond a "blank body," which looms in his mind as an unintelligible mass "without aperture, without entry" (47). Rather than providing some degree of resolution, uncovering the details of how the barbarian girl was tortured seems to simply loose the Magistrate's pursuit of understanding from whatever moorings it had, revealing to him an indefinite obscurity: "Of this one," he realizes, "there is nothing I can say with certainty" (48). Further, his erotic practice of reading her body becomes increasingly a source of frustration and even deeper confusion, "It is as if there is no interior," he reflects, "only a surface across which I hunt back and forth seeking entry" (49). The Magistrate weighs her incomprehensibility against his sexual transactions with the young prostitute at the inn, known as the Star: an opposition that provides us with considerable insights into the mechanism of his confusion.

In contrast to the barbarian girl's "closed, ponderous" body, "beyond comprehension" to the Magistrate, he finds it easy to "embrace [the Star], bury [himself] in her, lose [himself] in her soft bird-like flurries" (48). While having sex with the Star, the Magistrate registers that he "cannot even recall the other one's face," and moreover, at the mere thought of his inexplicable attraction to the other's "alien body," he notes, "I shudder with revulsion in the arms of my little bird-woman" (48). The juxtaposition of the Star's legibility and the impenetrable surface of the barbarian girl is all the more significant in light of the Magistrate's acknowledgement that, as a 
sex worker, the Star's relationship with him "is all playacting" (52). "I find I do not care," he admits, and instead of being perplexed by her explicitly hidden interiority, the Magistrate is easily and pleasantly "[c]aptivated by her performance" (52). What I find remarkable here is that the Star is immediately comprehensible to him, despite his being readily cognizant that her inner truth is being hidden from him, while his understanding balks at the total illegibility of the barbarian girl. Through the passages where the Magistrate compares the two women, the source of the barbarian girl's incomprehensibility comes into focus as she is steadily erased from the text altogether and, almost exclusively, referred to with some variation of "the other." That is, the Star's meaning is already given in her being present with the Magistrate; as another subject of the Empire, she is her own sign and requires no interpretation. Even the presence of unambiguous duplicity - the Magistrate's awareness of a performance that is taking place on the surface and obscuring her interiority—still occurs within a fixed and stable signification network, which remains intelligible to the Magistrate. ${ }^{4}$ Unlike the Star, the barbarian girl can only be perceived as a blank surface with an interiority that is inaccessible, either because it is hidden or because it does not exist. Put differently, as the other of the Empire, the barbarian girl's meaning is not given but rather, presumed absent; she is an undetermined signifier, and her body can only (or perhaps, must) be interpreted within the Magistrate's imperial discourse as a sign for something other than itself.

Exasperated by the barbarian girl's incomprehensibility, the Magistrate is compelled to exclaim, "She is incomplete!" and in this there is a certain key to understanding his "bewildered" fixation with her $(48 ; 49)$. When examined alongside the Star, the incompleteness of the

\footnotetext{
${ }^{4}$ It is not my intention here to overlook or uncritically accept the overarching system of patriarchy in which the Magistrate's interactions with both women are structured. I simply mean to note the disparity of legibility between them, throughout the various discourses of power at play, and recognize that the functions of patriarchy here merit their own discussion.
} 
barbarian girl takes on two dimensions. Most explicitly, she is perceived to be incomplete in the sense of the damage done to her body, the torture made manifest in the marks it has left her with: her body is, as it were, broken. Moreover, and as the Magistrate's continually frustrated efforts to understand her make apparent, she is incomplete in so far as, being other, she occurs within the Empire's discursive field as an undetermined signifier that must be interpreted in order to be known. While this plays out rather dramatically in the his "bewildered" confrontation with the impenetrable surface of her body, we also see the mechanics of her othering take place in the Magistrate's mundane interactions with the girl, as he develops a kind of familiarity with the girl (49). When the he relates to her the story of his personal crisis hunting the ram, "she says very firmly" to him, "If you want to do something, you do it," (45). The Magistrate, however, reflects: She is making an effort to be clear; but perhaps she intends, "If you had wanted to do it you would have done it." In the makeshift language we share there are no nuances. She has a fondness for facts, I note, for pragmatic dicta; she dislikes fancy, questions, speculations; we are an ill-matched couple. Perhaps that is how barbarian children are brought up: to live by rote, by the wisdom of the fathers as handed down. (45-46) Even her words cannot be taken as they are, but must be interpreted by the Magistrate into a coherent, intended meaning. Furthermore, the positive deductions he is able to draw from these interactions, her "fondness for facts" and "pragmatic dicta," her dislike of "fancy, questions, speculations," ultimately boil down to projections of his own meaning onto her apparent lack thereof. "I tell myself that she submits because of her barbarian upbringing," he reflects, shortly before deciding to help her return to her people, "But what do I know of barbarian upbringings? What I call submission may only be indifference" (63). That is, he comes to realize that, in his efforts to understand the girl, he is only capable of "casting one net of meaning after another over her," producing the very knowledge he believes himself to have discovered (94). The other is not, then, an undetermined signifier in the Empire's discursive network but an empty signifier. 
And this condition is both what incites the need to categorize or understand the other and why the other can, at bottom, have no fixed meaning - the discursive construction of the other is the occlusion of any referent.

Ultimately, this is the real cause of the barbarian girl's incompleteness - she is necessarily incomplete to him, because his knowledge or understanding of her can only ever be incomplete. It can never be complete because his liberal desire to understand the other is a product of the same discursive framework that produces the other as an indeterminate object of knowledge, one that must be interpreted to be understood. This interpretation can only occur as a production of knowledge about the other, just as the Empire produces knowledge about the barbarians. In this it is also clear why the object of the Magistrate's obsession shifts from deciphering her scars, in order to discover the details of her torture, to attempting to recall a memory of her before she was tortured and thereby marked. That is, he is attempting to recover an image of her before she was produced by the Empire as an essentially indeterminate other. However, the futility of his efforts to make her understood force us to recognize that this is only his continued confusion of cause with effect. The torture that Colonel Joll has subjected her to is merely the performance of her condition as other; it is not what othered her in the first place.

If we return to the scene where the barbarian girl finally reveals to the Magistrate the details of how her body was marked in torture, the gravity of this confusion takes on new significance. There are mounting ironies in the exchange around her confession and the parallels it conjures through her statements about her response to Colonel Joll's torture and interrogation, "But I had nothing to tell them. That was all," and her conclusion to the Magistrate, "But now it is getting better. The left eye is getting better. That is all” (47). In the persistence of his further questions - about yet unexplained scars, about what she "[feels] towards the men who did 
this"- the Magistrate unconsciously enacts the very situation that had spurred the terrors of his imagination when first confronted with the realities of Colonel Joll's profession (47). His insistence on further answers, on deeper truths in the barbarian girl's story, recalls his own terror-stricken appeal to Joll, "What if your prisoner is telling the truth . . yet finds he is not believed? Is that not a terrible position? Imagine: to be prepared to yield, to yield, to have nothing more to yield, to be broken, yet pressed to yield more!" (5). As we have already seen, this is only the beginning of the Magistrate's confrontation with the empty signifier of the other - the ever indeterminate, the ever as yet uninterpreted discursive condition of the barbarians, the object of knowledge about which meaning can only be produced because it has, at the outset, been denied. In this light we might recast the Magistrate's revelation, "With a shift of horror, I behold the answer that has been waiting all the time [to] offer itself to me in the image of a face masked by two black glassy insect eyes ... my doubled image cast back at me," his confrontation with the realization that his efforts to read the barbarian girl are only a reflection of Joll's interrogations (50).

Much has been made of this parallel, which constitutes one of the novel's primary tensions. Critics often characterize the Magistrate's search for answers in terms of reading, while Joll's is generally treated as writing. Lochner argues, "Colonel Joll functions as an executioner of the codes of Empire," proscribing through torture "the barbarian identity as enemy of state," whereas "the Magistrate becomes fixated on interrogating the significations of Empire," and this inquisitive nature "leads him to challenge Empire's claims to an objective knowledge of the other" (Lochner 240). Similarly, Spencer claims that the Empire's use of torture operates as an "imposition of ideological meanings on resistant texts, bodies and interlocutors," and that the Magistrate "gradually learns to appreciate that incidents and encounters are complicated and 
strange enough to warrant close scrutiny and therefore capable of contesting and even confuting .

. dominant "truth"' (Spencer 184). I would argue that, while these critics recognize the Magistrate's early relationship to the barbarian girl as a replication of Joll's interrogations, their emphasis on this distinction leads them to condemn the two's similarities in terms of a type of reading that is essentially writing.

There is little contention over the observation that Joll's use of torture is a form of marking, one that inscribes onto the body the status of other and barbarian (with all the accompanying significations), and thereby can be understood as a mode of writing in a performative sense - after all, the Magistrate shows himself to be very much under this impression. Nonetheless, the Magistrate's practice of reading, of seeking to uncover the truth, of trying to understand the other, as we see when we begin to interrogate the knowledge he acquires, is one that in fact produces the knowledge it then believes itself to have discovered. There are two conclusions that can be drawn from this. First, that the condition of being other is one that makes the body and person an undetermined signifier, a surface that cannot be taken to represent itself but must point to some other, hidden significance. That is, the other is denied interiority in the discursive field produced by systems of oppression that occasion their dehumanization to justify the violence done to them. Secondly, we can see that it is this condition of the other that incites the need to categorize and produce knowledge about them, knowledge which understands itself or takes the appearance of discovered understanding — an uncovering of hidden meaning that has, for one reason or another, been obscured from us.

As such, the reading/writing binary reveals itself as a false opposition: the Magistrate's practice of reading, well intentioned as it may be, can only occur as a simultaneous practice of writing (as any assumption of the other as a thing to be understood cannot occur without also 
establishing them as a site for the production of knowledge), just as Colonel Joll's acts of writing or marking the body with the signification of the Empire can only occur as an act of reading (as the production of meaning is inaugurated by a preexisting assertion that meaning is not given or self-evident but must be uncovered, by denying the presence of interior altogether). They are one and the same, incited by the same structure of imperialism, and I would suggest this is the significance of the Magistrate's revelation, "I was not, as I liked to think, the . . opposite of the cold rigid Colonel. I was the lie that the Empire tells itself when times are easy, he the truth that Empire tells when harsh winds blow" (156). He is here confronted with the realization that his liberal desires to understand and connect with the barbarian girl emerge from the discursive conditions produced by the system of Empire. Put differently, the liberal humanist logic of understanding is sparked by that same denial of humanity and subsequent inauguration of the other as an indeterminate object of knowledge, which must be interpreted. As such, the pursuit of understanding can only result in circular productions of knowledge, taking the shape of deciphering the other's indeterminateness. Our attempts to understand the other, to change the knowledge that is produced about them in the hopes of proving their denied humanity, emerge from and operate within the same discursive structures that require and authorize Joll's use of torture and interrogation. Any challenge to the other's oppression can only recapitulate the very logic of that oppression so long as it fails to see that the other is only a thing to be made visible/legible/understood under and through the system that oppresses them.

Obviously, this is not to say that the other's indeterminate position within imperialist discourse is simply a trick of the light or a matter of perspective - that recognizing the false premise on which the desire to understand the other (the initial denial of humanity, and thereby the interiority, that incites interpretation) would be sufficient to restore the other's intelligibility. 
The Magistrate cannot simply proclaim the self-evident meaning of the barbarian girl and experience her as her own sign, just as he cannot make her complete by deciphering her scars or remembering her as she was before Colonel Joll tortured her. As Boletsi notes, "The Magistrate has no choice but to employ the categories within which he himself has been constituted as a subject," and to the last, his experience of the girl is inextricable from their mutual positioning within the discursive network of the Empire (88). Moreover, I would note that, because the discursive positioning that constitutes his subjectivity is produced by the social arrangements and material structures of the Empire itself, the cognitive limitations that arise out of it are continually fixed under those conditions. This is made clear by the Magistrate's experience of being imprisoned and tortured as an enemy of the Empire, "when he comes to occupy [the barbarian girl's] place as a victim of torture" (Boletsi 80). Even as the Magistrate is subjected to a mock execution by hanging and strappado and he lapses into a vision of his meeting with the old nomad who took the barbarian girl back to her people, we find the Magistrate "waiting for him to speak" (138). We can see that his experiences have pushed him to the limits of his discursive constraints as an imperial subject in that, during this hallucination, he does not use the term barbarian, but simply refers to "the old man" and "the girl" (138). Nonetheless, he cannot surpass the limitations of his subjective constitution: "At any moment now he will speak," he thinks, "I must listen carefully to capture every syllable, so that later, repeating them to myself, poring over them, I can discover the answer to a question which . . . has flown like a bird from my recollection" (138). Even at the extremity of being reduced by the Empire to a similar position as the barbarians, an incomprehensible enemy of the state, the farthest he can reach beyond his discursive positioning is to recognize with a sigh, "What a pity. . . It is too late now" (138). 
Until the very end of the novel, the Magistrate remains incapable of comprehending the other; even being subjected to the same conditions does nothing to make the barbarian others any more knowable. But in this lie the very small victories available to him: the recognition and acceptance of the other's unknowability, his realization of the complicit role his liberal humanist desire to understand the other plays in upholding the very conditions that oppress them, and an awareness of the incapacity to change those conditions through empathetic recognition within the structures of the Empire. We can find the significance of this victory in his thoroughly analyzed reading of the poplar slips before Colonel Joll. When he looks over the symbols he has spent so many hours seeking to decipher, his questions, "Does each stand for a single thing, a circle for the sun, a triangle for a woman, a wave for a lake; or does a circle merely stand for 'circle', a triangle for 'triangle', a wave for 'wave'?” reflect his acceptance of the indeterminate signs of the other (127). He has come to recognize that any attempt to better understand the other is also a recapitulation of their fundamental, unknowable otherness.

That the Magistrate never comes to an understanding of the other is, then, not a failure but a victory in so far as it recognizes the futility of that line of self-perpetuating reasoning. As he says, "The knot loops in upon itself; I cannot find the end" (23). The novel is not an indication to us of the better means by which we might successfully understand the other. Instead, it establishes the impossibility of operating within the discursive field of the Empire in the hopes of dismantling the system that produces it. The Empire is predicated on the oppression of the barbarians, and ending the latter necessarily entails ending the former. Only then will the other cease to be other, and their meaning will be given in their being as our own is. Given my critique of scholars' tendencies to project their own questionable perspectives onto the function of the novel, I would do myself no favors by replicating those efforts with different results. While I 
maintain that the novel exposes the incapacity of liberal humanism to challenge structures of oppression, it is clear that the novel is by no means a revolutionary tract or a handbook for effective resistance. The Magistrate does not rush out to aid the barbarians in overthrowing the Empire. I have no interest in claiming that the text serves a specific function or does anything in particular, but it does appear that the text contains indications of what the end of the other's oppression would necessitate.

The Magistrate, in a self-critical reflection on his outrage at Colonel Joll's inhumanity, recognizes that his liberal position equates to nothing more than "an archaic code of gentlemanly behavior towards captured foes ... [standing] against ... the new science of degradation that kills people on their knees, confused and disgraced in their own eyes" (124). He remarks cynically, "Easier to shout No! Easier to be beaten and made a martyr. Easier to lay my head on a block than to defend the cause of justice for the barbarians," but what is of immediate interest to us is how he outlines what that justice could possibly mean (124). "For where can that argument lead," he wonders, "but to laying down our arms and opening the gates of the town to the people whose land we have raped?" (124-125). Significantly, the question of justice appears again when the Magistrate "translates" the poplar slips for Colonel Joll and Mendel. Taking up one of the symbols, he tells them, "It is the barbarian character for war, but it has other senses too. It can stand for vengeance, and, if you turn it upside down like this, it can be made to read justice" (128-129). Spencer interprets this moment as “the Magistrate's first articulated insights into the Empire's violence and its consequences," but cites only the mentions of "war" and "vengeance" (Spencer 185). Other treatments of the Magistrate's allegorical translations similarly overlook the question of justice implicit in the scene. 
Ironically, but certainly fitting to this consideration, the Magistrate notes, "There is no agreement among scholars about how to interpret these relics of the ancient barbarians" (Coetzee 129). While, again, it is not my intention to argue against other critical interpretations in order to propose my own normative claim about the overall function of the novel, I would like to point out that the novel leaves open the potential to take seriously the implications of these scenes when read together. That is, we are invited to consider that what might be seen in the barbarian's actions as "vengeance" or "war" may in fact be the very precondition of justice for the barbarians: the destruction of the walls, of the forts, of the Empire's very foundations - the total collapse of the structures that protect the subjects of the Empire, that constitute them as subjects in the first place, and that cannot remain without perpetuating injustice. It is with this insight in mind that I would like to return to my initial consideration of the Magistrate's final thoughts about the barbarian girl:

"Perhaps when the barbarians come riding in," I say, "she will come riding with them." I imagine her trotting through the open gateway at the head of a troop of horsemen, erect in the saddle, her eyes shining, a forerunner, a guide, pointing out to her comrades the lay of this foreign town where she once lived. "Then everything will be on a new footing."

If we take seriously this reading of the question of justice for the barbarians, it may be possible to recontextualize the apocalyptic atmosphere that envelopes the fort as the Magistrate and the townspeople anticipate the coming of the barbarians. That is, the question of levelling ourselves with the other, the possibility of a time when "everything will be on new footing," the end of the other's oppression and dehumanization, does not depend on coming to understand them from within the walls of our own empires.

In fact, as the Magistrate has come to reconcile with himself, it is the existence of those walls that maintain the fundamental unknowability of the other. Ultimately the Magistrate goes 
no further than accepting that the other is fundamentally unknowable to the subjects of the Empire, and that desiring to know them is not a challenge to their oppression but a reflection of it. I would further contend that the other's position within discourses of power, as an empty signifier, is inescapable precisely because our discursive constitutions are not free floating and spontaneous, but rather, they are produced by the material structures of power and domination within which we exist. To end the violent oppression of the people those systems of power produce as others is not a matter of accepting their condition of indeterminacy - the dehumanization that legitimizes the other as an object of knowledge in the first place—and seeking to change the kind of knowledge that is produced about them for the better. Counteracting the dehumanization of the other is not a question of understanding them, but of ending the social arrangements that produce our co-constitutive discursive field, in which the other can only be understood through interpretation. I do not wish to argue that this is the lesson the novel unquestionably teaches us. Moreover, I do not care about what the text actually does, what function it serves - it is only my intention to suggest that this is one of the ways we might read the text, one lesson we might construct from the material available to us, and certainly one that seems honest to the novel's evident disavowal of liberal humanist modes of opposition to violence and oppression. To return to Boletsi's essay, I would argue that if we walk away from the novel believing that it simply appeals to the prospect "of a society that would ... be more open to an encounter with others," in a manner of speaking, society with greater capacities for translation, we will only be left—and in a manner more alike the town than the Magistrate by the novels' end — waiting (94). Instead, let us concern ourselves with the very real conditions that necessitate violence and oppression, that produce the discursive other, in the first place - the material walls around the empire we live in, and the daily practices of violent exploitation which 
uphold them, are the foundations on which the walls of discursive occlusion are founded. The latter will not come down without our systematic destruction of the former. 


\section{A Digressionary Note on Humanism}

Although I am more interested in how radically Robert Spencer's thinking departs from the novel, it would bear a kind of shame not to at least comment on the logic behind Spencer's absurd, and in no small measure pious, appeal to "a respect for the rule of" human rights "law" (186; emphasis added). After all, who enforces human rights laws but global institutions that are already dominated by the imperial powers of the world and largely function as a vehicle for those powers' collective interests? And, for that matter, when have human rights laws been called on to exert international intervention, except against nations that (rightly or wrongly) find themselves at odds with the global powers that be? Moreover, where do our ideas and practices of human rights come from? As perhaps the asymmetric applications of international human rights laws ought to make unsurprising, the concept of human rights emerge out of Enlightenment era liberal theory — that is, the philosophy that arose out of the greatest expansion of colonialism and slavery in history to be the dominant ideology of the responsible societies. Furthermore, the implementation of Spencer's celebrated international human rights statutes is almost entirely the work of the 'western' capitalist allies who were horrified by the Nazi regime and yet more than happy to continue its tactics — or rather, to continue the tactics that the Nazis had learned from them — anywhere beyond the pale of Europe. From a historically inclined perspective, one might say that the atrocities of the war on terror, which rightly concern Spencer, are not so much a failing in respect for international human rights as they are prominent instantiations of the built-in blind spots that have always been at the core of that practice of humanism by which Spencer would have us save ourselves. 


\section{Works Cited}

Blair, Peter. "The Liberal Tradition in Fiction." The Cambridge History of South African Literature, edited by David Attwell and Derek Attridge, Cambridge University Press, 2012, pp. 474-499.

Boletsi, Maria. "Barbarian Encounters: Rethinking Barbarism in C. P. Cavafy's and J. M. Coetzee's Waiting for the Barbarians." Comparative Literature Studies, vol. 44 no. 1, 2007, pp. 67-96. Project MUSE, doi:10.1353/cls.2007.0027.

Coetzee, J. M. Waiting for the Barbarians. Penguin Books, 2010.

Lochner, Liani. "Literary Form and Contesting the Subject in J. M. Coetzee's Waiting for the Barbarians and Avarind Adiga's The White Tiger." Aesthetics and Ideology in Contemporary Literature and Drama, edited by Agostini René and Madelena Gonzalez, Cambridge Scholars Publishing, 2015, pp. 235-237.

Spencer, Robert. “J. M. COETZEE AND COLONIAL VIOLENCE.” Interventions, vol. 10, no. 2, 4 July 2008, pp. 173-187. doi:10.1080/13698010802145085. 